NBER WORKING PAPER SERIES

\title{
POSITIVE AND NEGATIVE MENTAL HEALTH CONSEQUENCES OF EARLY CHILDHOOD TELEVISION WATCHING
}

\author{
Michael Waldman \\ Sean Nicholson \\ Nodir Adilov \\ Working Paper 17786 \\ http://www.nber.org/papers/w17786
NATIONAL BUREAU OF ECONOMIC RESEARCH
1050 Massachusetts Avenue
Cambridge, MA 02138
January 2012

We thank Doug Almond, Andrew Epstein, Vrinda Kadiyali, Jonathan Ketcham, and Jonathan Skinner for comments on previous drafts, Rebecca Kumar, Marissa Amiraian, and Jenna Kerner for excellent research assistance, and Cornell's Institute for the Social Sciences for financial support. The views expressed herein are those of the authors and do not necessarily reflect the views of the National Bureau of Economic Research.

NBER working papers are circulated for discussion and comment purposes. They have not been peerreviewed or been subject to the review by the NBER Board of Directors that accompanies official NBER publications.

(C) 2012 by Michael Waldman, Sean Nicholson, and Nodir Adilov. All rights reserved. Short sections of text, not to exceed two paragraphs, may be quoted without explicit permission provided that full credit, including $\odot$ notice, is given to the source. 
Positive and Negative Mental Health Consequences of Early Childhood Television Watching Michael Waldman, Sean Nicholson, and Nodir Adilov

NBER Working Paper No. 17786

January 2012

JEL No. I12

\begin{abstract}
$\underline{\text { ABSTRACT }}$
An extensive literature in medicine investigates the health consequences of early childhood television watching. However, this literature does not address the issue of reverse causation, i.e., does early childhood television watching cause specific health outcomes or do children more likely to have these health outcomes watch more television? This paper uses a natural experiment to investigate the health consequences of early childhood television watching and so is not subject to questions concerning reverse causation. Specifically, we use repeated cross-sectional data from 1972 through 1992 on county-level mental retardation rates, county-level autism rates, and county-level children's cable-television subscription rates to investigate how early childhood television watching affects the prevalence of mental retardation and autism. We find a strong negative correlation between average county-level cable subscription rates when a birth cohort is below three and subsequent mental retardation diagnosis rates, but a strong positive correlation between the same cable subscription rates and subsequent autism diagnosis rates. Our results thus suggest that early childhood television watching has important positive and negative health consequences.
\end{abstract}

Michael Waldman

Johnson Graduate School of Management

323 Sage Hall

Cornell University

Ithaca, NY 14853-6201

mw46@cornell.edu

Sean Nicholson

Professor

Department of Policy Analysis and Management

Cornell University

102 Martha Van Rensselaer Hall

Ithaca, NY 14853

and NBER

sn243@cornell.edu

\author{
Nodir Adilov \\ Indiana University - Purdue University \\ Neff Hall \\ Fort Wayne, IN 46805 \\ adilovn@ipfw.edu
}




\section{Introduction}

Possibly the most significant change in the lives of young children in the US and other developed countries since the middle of the twentieth century is the growing exposure of young children to television and other types of screen media such as videos and DVDs. Prior to 1950 the amount of time a typical young child spent watching television and other types of screen media was zero since television was only widely introduced in the US around 1950. In contrast, the Kaiser Family Foundation (2006) reports that among their 2005 nationally representative sample of parents, 70 percent or more of children under two and over 90 percent of children two to three watched television or other types of screen media several times a week or more. Further, the amount of watching was frequently substantial with 36 percent of children under two watching one or more hours per day and 70 percent of children two to three watching this much. 1

Almost since the introduction of television there have been concerns about how television and other screen media affects childhood development. Early on most of these concerns and most of the studies focused on older children, possibly because it was thought and was probably the case that television watching by very young children was quite limited. But with the growth of cable television and channels targeted at young children, the introduction of VCRs and DVDs, and the growth of multitelevision households and televisions in childrens' bedrooms, television watching and exposure to other screen media for the very youngest children has grown and is now quite substantial. And with this growth in exposure there has been a corresponding growth in interest and studies concerning how this increased exposure affects childhood development.

Over the last 20 years there have been numerous studies in the medical literature of this issue and many of the studies find that early childhood television watching is associated with various negative

\footnotetext{
${ }^{1}$ See also Kaiser Family Foundation (2003), Roberts and Foehr (2004), and Anderson and Pempek (2005) for additional evidence and discussions. In the remainder of the paper we sometimes use the term "television" to refer to various activities a young child might participate in where the child views changing electronic images projected onto a screen. These include watching television, watching videos and DVDs, watching movies in a movie theater, and watching a computer screen. Existing evidence on the issue such as in Kaiser Family Foundation $(2003,2006)$ indicates that almost all of this viewing for children under the age of three, which is the age group our paper focuses on, takes the form of watching television, videos, and DVDs.
} 
health outcomes such as impaired language development and cognitive development and behaviors consistent with attention deficit hyperactivity disorder (see Christakis (2009) for a recent review). As a result, the American Academy of Pediatrics now recommends no television watching before age two and limited watching after that (American Academy of Pediatrics Committee on Public Education, 2001). But a drawback is that almost all of these studies show correlations but do not address causality. For example, the finding of a positive correlation between early childhood television watching and problems concerning cognitive development could be due to television watching causing these problems. But it could also be due to reverse causation, i.e., children more prone to having these problems are more attracted to television.

In this paper we consider health consequences of early childhood television watching but avoid the problem of reverse causation by using a natural experiment methodology. ${ }^{2}$ In particular, we focus on the time period 1972 to 1992 that includes the time period in which children's cable stations (such as Disney and Nickelodeon) were introduced in many counties and grew substantially. If, as is likely and we will provide evidence for, a cable subscription in a household that includes one or more children's cable stations increases early childhood television watching, then at the county level the growth in children's cable should be correlated with the frequency of negative health outcomes if early childhood television watching does indeed have deleterious effects on childhood development. This approach avoids the problem of reverse causation as long as families prone to having a child with the negative health outcome under investigation do not locate disproportionately in counties with growing children's cable subscription rates.

We use this approach to study the relationship between early childhood television watching and two health outcomes - mental retardation and autism. We study mental retardation because, if early childhood television watching causes problems concerning cognitive development, then it would be natural for it to also result in an increase in the frequency of mental retardation diagnoses since an

\footnotetext{
${ }^{2}$ See Rosenzweig and Wolpin (2000) for a discussion of the natural experiment methodology.
} 
individual is typically diagnosed with mental retardation when his or her IQ is below some threshold (typically 70 or 75 ). We study autism because a number of previous papers have discussed the possibility that early childhood television watching may be a trigger for autism. ${ }^{3}$ Also, since early childhood television viewing has been connected to attention problems and attention problems are one of the hallmarks of autism, it seems natural to investigate whether early childhood television watching is a trigger for autism.

In our investigation of the correlations between children's cable subscription rates at the county level and county-level diagnoses of mental retardation and autism, we focus on birth cohorts between 1972 and 1992 in California and Pennsylvania counties. We investigate post-1971 birth cohorts because there are no data available for earlier cohorts, while the analysis is restricted to pre-1993 birth cohorts because after that time period satellite television became important and we do not have data on satellite television subscription rates. We focus on California and Pennsylvania because to the best of our knowledge those are the only two states with detailed county-level autism data during this time period. Our empirical approach is to investigate the correlations between the average children's cable subscription rate in a county when a cohort is below three and subsequent mental retardation and autism diagnosis rates for the cohort. We estimate regressions that include county fixed effects and birth cohort fixed effects. Also, since including county fixed effects will not fully control for the effects of county variables on health outcomes if the introduction and growth of children's cable is correlated with timevarying county variables, most of our regressions also include either time-varying demographic variables or county-specific time trends. The effect of children's cable is identified by within-county changes in children's cable subscription rates over time.

Our main finding is that the average children's cable-television subscription rate when a countylevel cohort is below three is negatively correlated with subsequent mental retardation rates but positively correlated with subsequent autism diagnosis rates. We find the negative correlation with subsequent

\footnotetext{
${ }^{3}$ See McDowell (2004,2010), Nair (2004), Bazar et al. (2006), Easterbrook (2006), and Waldman, Nicholson, and Adilov (2006).
} 
mental retardation rates both when we do not include either time-varying demographic variables or county-specific time trends and when we include time-varying demographic variables. But we do not find the negative correlation when we include county-specific time trends. On the other hand, we find the positive correlation with subsequent autism diagnosis rates under all three specifications.

We also provide additional tests to better understand the nature and sources of these correlations. For example, we consider the cable subscription rate in each of the three years that a cohort is under three. We do this in order to investigate whether it is the average children's cable subscription rate over the three years that matters or whether results are driven by the children's cable subscription rate at a specific age or ages. For mental retardation most of the evidence points towards a negative correlation between subsequent mental retardation rates and children's cable subscription rates when cohorts are two years old, and little or no correlation between mental retardation rates and children's cable subscription rates when cohorts are either zero or one year old. For autism there is clear evidence of a positive correlation between subsequent autism diagnosis rates and children's cable subscription rates when cohorts are one year old and some evidence of a positive correlation when cohorts are zero years old. Our findings thus suggest negative mental health consequences for children's television watching before age two and positive health consequences for television watching at age two.

This paper builds on the research of Gentzkow and Shapiro (2008). They were also concerned with the idea that most of the medical literature concerning the effects of television watching on childhood development is subject to various problems. They addressed the problems using data from a natural experiment - the introduction of television across US cities between the late 1940s and early 1950 s - to investigate the effect of television watching on cognitive development, which they measured using standardized test scores during adolescence. Our approach is similar in that we also employ a natural experiment - the growth of children's cable between 1972 and 1992. Further, our results concerning cable and mental retardation are similar to their findings in that both suggest that television watching sometimes has positive effects on cognitive development. At the end of Section II we discuss their paper and the relationship between our papers in more detail. 
As a final introductory point, there is a potential explanation for our findings other than that early childhood television watching has a negative causal effect on mental retardation rates and a positive causal effect on autism diagnosis rates. That is, it is possible that one or both of the correlations we find is spurious and is in fact due to some as yet unknown other factor or factors that are correlated with the growth of children's cable. We attempt to control for such factors by including time-varying demographic variables or county-specific time trends in our regressions, but even in the case of autism diagnosis rates where our results are robust to both approaches the possibility of there being a different trigger for autism correlated with children's cable is not completely ruled out. We discuss this issue further in Section V.

The outline for the paper is as follows. Section II discusses the previous literature on the effects of early childhood television watching on health and development outcomes. Section III uses PSID timeuse data to examine whether the presence of cable in a household is associated with increases in early childhood television watching. Section IV presents our analysis of the correlation between children's cable and mental retardation and the correlation between children's cable and autism. Section V discusses the magnitudes of the correlations we find and potential issues concerning our empirical methodology. Section VI presents concluding remarks.

\section{Previous Literature}

As indicated in the introduction, there is an extensive medical literature on the effects of early childhood television watching on health and development outcomes. In this section we briefly describe this literature, then discuss a paper mentioned above, Gentzkow and Shapiro (2008), which is a recent economics paper on the topic, and then briefly discuss the literature concerning causes of autism. Anderson and Pempek (2005), Murray and Murray (2008), Kirkorian, Wartella, and Anderson (2008),

and Christakis (2009) recently reviewed the medical literature on early childhood television watching and childhood development. 
The medical literature looks at the possible effects of early childhood television watching on a large number of health and development outcomes including language development, cognitive development, sleep problems, the development of social skills, and the development of later behaviors consistent with attention deficit hyperactivity disorder. Much of this literature finds a positive correlation between the amount of television watching in early childhood and the frequency of negative health and development outcomes. Findings in this literature include a positive correlation between early childhood television watching and problems concerning language development (see, for example, Linebarger and Walker (2005) and Zimmerman, Christakis, and Meltzoff (2007)) and cognitive development (see, for example, Zimmerman and Christakis (2005)). There is also evidence of a positive correlation between early childhood television watching and later behaviors consistent with attention deficit hyperactivity disorder (see, for example, Christakis et al. (2004) and Landhuis et al. (2007)).

The drawback of this literature is that almost all of the studies show correlation but do not demonstrate causation. For example, consider the well known study of Christakis et al. (2004) concerning attention deficit hyperactivity disorder (ADHD). In this study the authors employ national health surveys to show a positive correlation between early childhood television watching and behaviors at age seven consistent with ADHD. So one possibility is that increased early childhood television viewing serves to trigger or cause attention deficit hyperactivity disorder. But another possibility is that children who are likely to develop the condition in the future are more drawn to television and, as a result, watch more of it. Because the vast majority of the studies in this literature are characterized by this or similar problems, there is really little we know definitively from the medical literature concerning the plusses and minuses of early childhood television watching.

One additional aspect of this literature is worth pointing out, however. According to the medical literature the effects of childhood television watching varies by the age of the child and by the program content (see Anderson and Pempek (2005) and Kirkorian, Wartella, and Anderson (2008) for discussions). For very young children the evidence suggests that children learn more effectively from real-life experiences than from television watching and, as indicated, a number of studies find a 
correlation between television watching and negative development and health outcomes. For preschool children, however, the evidence suggests that television watching can be either good or bad depending on the program content (there is also some evidence that program content can be important for the effects of television watching on younger children). On the positive side, a number of studies find benefits such as increased problem solving skills and improved school readiness associated with preschool television watching of educational programming such as Blue's Clues and Sesame Street. On the negative side, however, preschool watching of violent cartoons such as Batman and Superman has been found to be positively correlated with behavior problems. 4

Gentzkow and Shapiro (2008) is an economics paper on the subject that uses a natural experiment methodology similar to our approach. They use variation in the dates of introduction of television across US cities between the late 1940s and early to mid 1950s to investigate how preschool television watching affects standardized test scores during adolescence. Most of their point estimates are consistent with a positive rather than a negative effect of preschool television watching, where for reading and general knowledge scores these positive effects are marginally statistically significant. Further, their evidence is consistent with these positive effects being larger, and possibly confined to, children from disadvantaged backgrounds.

Note that one important difference between the Gentzkow and Shapiro study and our study is the ages of the children when the television watching occurred. Our focus is on early childhood television watching, which for our empirical work we define as occurring prior to age three. On the other hand, Gentzkow and Shapiro focus on preschool television watching which in their empirical analysis means television watching between ages two and six. This is an important difference because, as discussed above, there is a distinction in the medical literature concerning the effects of television watching on these two age groups. So finding positive effects associated with preschool television watching is arguably not

\footnotetext{
${ }^{4} \mathrm{~A}$ few of the studies in this literature employ experimental designs that allow the researchers to show both correlation and causation. See, for example, Friedrich and Stein (1973).
} 
that surprising. But finding any positive effects of early childhood television watching would be quite different than what is suggested by most of the medical literature on the topic.

Finally, in terms of research on the causes of autism, numerous studies have found evidence in favor of a genetic component such as the early twin study of Folstein and Rutter (1977). But many also believe that environmental triggers are important - see, for example, Institute of Medicine (2008). For example, Hallmeyer et al. (2011) conclude from an analysis of data on twins in California that environmental factors common to twins explain over half of the autism cases in their sample. A number of studies have identified potential environmental triggers such as air pollution in Windham et al. (2006), agricultural pesticides in Roberts et al. (2007), and exposure to phthalates in Larsson et al. (2009). But no one argues that prior literature has investigated all the potentially important environmental triggers and, in particular, there is basically no prior empirical literature focused on the possibility that early childhood television watching may be a trigger for autism other than our own previous working paper (Waldman, Nicholson, and Adilov, 2006). 5

\section{Cable Television and Early Childhood Television Watching}

It seems intuitive that early childhood television watching will on average be higher in counties with higher cable subscription rates and that this should be especially true in counties with higher children's cable subscription rates, where by a children's cable subscription we mean a cable subscription that includes one or more channels targeted at young children such as Disney and Nickelodeon.

Nevertheless, given the importance of our interpretation in the next section that early childhood television watching rises with the children's cable subscription rate, in this section we provide evidence that young children in counties with a high children's cable-television subscription rate indeed watch more television. Note that throughout the paper we focus on children below age three because, as discussed

\footnotetext{
${ }^{5} \mathrm{We}$ improve on the analysis in our earlier working paper in various ways including providing evidence consistent with early childhood television watching increasing when there is cable in the household, showing results are robust to the introduction of time-varying demographic variables and county-specific time trends, and exploring agespecific cable subscription rates.
} 
earlier, in most of the medical literature on the subject it is television watching before age two or three that is thought to be especially problematic.

\section{A) Data and Method for the Cable-Early Childhood Television Watching Analysis}

The data used in this section are taken from the 1997 Child Development Supplement to the Panel Study of Income Dynamics (PSID), the Television and Cable Factbook, and the census. In the PSID each of several thousand parents completed a time use survey for their child by recording how many minutes the child spent on each of several activities during one randomly chosen weekday and one randomly chosen weekend day, where television watching (including videos) was one of the activities recorded. This survey resulted in time-use data for 645 children under the age of three.

We begin our analysis by focusing on the correlation between early childhood television watching and the general cable television subscription rate. For each cable television company, the Television and Cable Factbook, published annually, reports the number of households that subscribe to cable, the primary community served, and the county or counties served. The percentage of households subscribing to cable is derived by dividing subscriptions by the number of households in a county or independent unit (IU), as reported by the census. ${ }^{6}$ Although we do not have data on whether a particular household subscribed to cable, we do observe each PSID household's county of residence and assign to them the average area cable subscription rate. Note that the public version of the PSID indicates the state where each surveyed household lived in 1997. Because there is substantial variation in cable subscription rates across counties within a state, we obtained from the PSID the 1997 county of residence for each household in order to more precisely measure the relevant cable subscription rate. ${ }^{7}$

Using ordinary least squares, we regress the number of minutes a child watched television

\footnotetext{
${ }^{6}$ Mental retardation and autism diagnoses in Pennsylvania are reported by IU, which are single counties or groups of contiguous counties, rather than by county.

${ }^{7}$ We dropped from our sample households living in counties in the top one percent of the county cable-subscriptionrate distribution. These counties had cable subscription rates significantly above 100 percent, where this is likely due to large numbers of hotels and motels in the county.
} 
and videos on a surveyed day on the general cable subscription rate and/or the children's cable subscription rate for the household's county of residence:

$$
\mathrm{TV}_{\mathrm{i}}=\beta_{1}+\beta_{2} \text { Cable }_{\mathrm{i}}+\boldsymbol{\beta}_{3} \mathbf{X}_{\mathbf{i}}+\boldsymbol{\beta}_{\mathbf{4}} \mathbf{Z}_{\mathbf{i}}+\varepsilon_{\mathrm{i}}
$$

$\mathrm{TV}_{\mathrm{i}}$ is the measured television viewing time of child $\mathrm{i}, \mathbf{X}_{\mathbf{i}}$ is a vector of individual and family control variables, $\mathbf{Z}_{\mathbf{i}}$ is a vector of state indicator variables, and $\varepsilon_{\mathrm{i}}$ is an error term. We include various controls in $\mathbf{X}$ : indicator variables for whether the survey day occurs on a weekend, six-month age intervals for the child, gender, race, and controls for household characteristics (family income, whether there is a single head of household, mother's education level measured in years, and whether the mother works). ${ }^{8} \mathrm{We}$ also include average household income in the county to account for the possibility that peer effects at the household level can affect a child's television watching. Additionally, we include state fixed effects, so the effect of cable is identified by variations between counties within a state. We adjust the standard errors to allow error terms to be correlated between individuals within a county. ${ }^{9}$ As indicated, in some specifications we include the children's cable subscription rate instead of or in addition to the general cable subscription rate.

\section{B) Results}

As indicated above, we do not observe whether specific households in the PSID data set subscribe to cable. We do have the cable subscription rate for the household's county of residence, which should be correlated with whether a specific household has a cable subscription. The logic here is that the higher the cable subscription rate in the county of residence the higher is the probability the household has a cable subscription.

Results, which are reported in column 1 of Table 1, are consistent with the hypothesis that the presence of cable in a household increases the amount of television viewed by children under the age of three, on average. That is, the coefficient on the general cable variable is positive and statistically

\footnotetext{
8 We use the father's education when the mother is not in the household.

${ }^{9}$ Results are similar if we cluster standard errors at the individual level rather than the county level.
} 
significant at the five-percent level. Note further that this coefficient indicates that a 10 percentage point increase in the general cable subscription rate is associated with an increase of just over three minutes of television watching per day, on average. Since the effect should only occur (or mostly occur if there are peer effects) in the additional households subscribing to cable, this result indicates that having a cable subscription increases the amount of early childhood television watching by about 30 minutes per day. 10 Since average television watching in our sample of children under three is approximately 70 minutes per day, our results suggest that having a cable subscription results in a large percentage increase in the amount of time a young child watches television.

We now consider the effects of children's cable channels on early childhood television watching. That is, maybe it is not a cable subscription per se that increases early childhood television watching, but rather the effect occurs only or primarily with cable subscriptions that include one or more channels targeted at young children. In column 2 of Table 1 we investigate this by repeating the regression after substituting a children's cable subscription variable for the general cable subscription variable employed in column 1. To construct this variable we include all cable subscriptions that included a children's channel in the basic cable package (Nickelodeon was sometimes included in the basic package while Disney and the Cartoon Network were never included) and all cable subscriptions where a children's cable channel was not part of the basic cable package but the subscriber paid extra to receive a children's channel such as Disney.

The results are reported in column 2 of Table 1. Comparing columns 1 and 2 we see that the coefficient on the children's cable television rate variable in column 2 is larger than the coefficient on the general cable subscription rate variable in column 1. Also, the coefficient on the children's cable subscription rate variable in column 2 is statistically significant at the one-percent level while the coefficient on the general cable subscription rate variable in column 1 is statistically significant at the

\footnotetext{
${ }^{10}$ For this calculation we assume that a 10 percentage point increase in the cable subscription rate in a county translates into a 10 percentage point increase in the probability a household in the county with a child under three subscribes to cable. Since the actual increase may be larger or smaller than this assumed value, our estimate of 30 minutes per day may be an overestimate or an underestimate of the true effect that a cable subscription in a household has on the amount of early childhood television watching.
} 
five-percent level. In column 3 we include both cable variables and find that when both are included neither is statistically significant at standard confidence levels, although the children's cable variable coefficient is much larger than the coefficient on the general cable variable. That neither coefficient in column 3 is statistically significant is likely due to the high correlation between the variables which is approximately 0.78 .

On net, we believe Table 1 points more strongly to a cable subscription with a children's channel having a positive effect on early childhood television watching than a cable subscription that does not include such a channel having this type of positive effect. With this in mind, in later regressions we focus on children's cable-television subscription rates, where, as above, this means the rate for subscriptions that include one or more channels targeted at young children. ${ }^{11}$

\section{Chidlren's Cable Televison, Mental Retardation, and Autism}

In this section we investigate whether at the county level children's cable-television subscription rates are correlated with mental retardation rates and autism diagnosis rates. We begin by describing the data.

\section{A) Data for the Children's Cable-Mental Retardation/Autism Analysis}

For the children's cable-mental retardation/autism analysis we focus on children born between 1972 and 1992. In later years satellite television became important and we do not have data concerning satellite subscription rates and 1972 is the earliest date that data are available. ${ }^{12}$ The two states for which autism data are available for this time period are California and Pennsylvania. Thus, to keep our analysis

\footnotetext{
${ }^{11}$ Most of the results in the next section are qualitatively unchanged if we substitute general cable variables for the children's cable variables we employ.

12 The fact that satellite became important by the mid to late 1990s is important for the analysis in this section because we focus on children's cable variation within a county over time. That is, in later years changes in the children's cable subscription rates over time may be poor measures of what is happening to the sum of children's cable plus children's satellite subscriptions over time. In contrast, because of the cross-sectional nature of the tests in Section III, the presence of satellite is less of a problem in Section III as long as higher children's cable subscription counties are also counties with higher children's cable plus children's satellite subscription rates.
} 
of mental retardation comparable to our autism analysis, we also restrict our mental retardation analysis in this section to California and Pennsylvania. The California Department of Developmental Services reports, separately by child's age and county of residence, the number of children receiving services at a regional developmental services center in December 1990 diagnosed with mental retardation and the number diagnosed with autism. ${ }^{13}$ We used these data and census population data to calculate a mental retardation rate and an autism rate for each California county for each cohort of individuals born between 1972 (age 18 in 1990) and 1982 (age 8 in 1990). We also calculate mental retardation rates and autism diagnosis rates for eight-year olds in December 1991 (i.e., children born in 1983) through 2000 (i.e., children born in 1992) in a similar manner using California Department of Developmental Services mental retardation and autism diagnosis counts and census data for each respective year. The complete data set consists of mental retardation rates and autism diagnosis rates by county for each cohort of children born between 1972 and 1992.

The Pennsylvania Department of Education provides mental retardation counts and autism diagnosis counts for intermediate units (IUs) rather than counties, where an IU is either a populous county or a grouping of less populous counties. Following the method just described, we calculate mental retardation rates and autism diagnosis rates by IU for each cohort of children born between 1972 and 1992.

To construct children's cable subscription percentages we employ the Television and Cable Factbook. For each cable television company, the Television and Cable Factbook, published annually, reports the number of households that subscribe to cable, the primary community served, and the county or counties served. We sum subscription data across all cable companies serving a county or IU in each year between 1972 and 1992, which spans the period when at least one of the cohorts of children described above was below age three. Also, because our focus is children's cable subscription rates we only include subscriptions that include at least one channel targeted at young children. The percentage of

\footnotetext{
${ }^{13}$ See Department of Developmental Seervices $(1999,2003)$ for detailed discussions of the California data as regards autism.
} 
households subscribing to children's cable is derived by dividing subscriptions by the number of households in a county or IU, as reported by the census.

Some of our regressions include a measure of annual precipitation. The National Climatic Data Center records daily precipitation for more than 8,000 weather stations in the United States. To calculate precipitation in a specific county or IU in a particular year, we first average precipitation across all weather stations in the county or IU for each day of the year. We sum the resulting values across all days in the year to get annual precipitation, and then calculate average annual precipitation by county and IU for each three-year interval when the 1972 to 1992 birth cohorts were under three.

\section{B) Empirical Methodology}

Because there is no large scale study of early childhood television viewing that would allow us to directly test the health effects of such viewing, we rely on a natural experiment. Consistent with results in the previous section, because children's cable expands channel offerings and provides one or more channels whose target audience is young children, early childhood television viewing should be higher on average for families with a children's cable subscription than for those without. We thus test whether mental retardation rates and autism diagnosis rates for cohorts of children in a county/IU are correlated with the county/IU children's cable subscription rates when cohorts are young. Specifically, we regress mental retardation rates and autism diagnosis rates for each birth cohort in California counties and Pennsylvania IUs between 1972 and 1992 on the average annual children's cable subscription rate these cohorts experienced in that county/IU when the cohort was under three:

$$
\mathrm{Y}_{\mathrm{k}, \mathrm{b}}=\alpha_{1}+\alpha_{2} \text { Cable }_{\mathrm{k}, \mathrm{b}}+\boldsymbol{\alpha}_{3} \mathbf{Z}_{\mathrm{k}}+\boldsymbol{\alpha}_{4} \operatorname{Cohort}_{\mathrm{b}}+\varepsilon_{\mathrm{k}, \mathrm{b}}
$$

In equation (2), $\mathrm{Y}_{\mathrm{k}, \mathrm{b}}$ denotes the mental retardation or autism rate (or the log of the rate in some specifications) in county or IU k for birth cohort $\mathrm{b}, \mathrm{Cable}_{\mathrm{k}, \mathrm{b}}$ is the average percentage of households with children's cable in county or IU k over the years that cohort b was below the age of three, $\mathbf{Z}$ is a set of county or IU fixed effects, and Cohort is a set of birth cohort fixed effects. The focus of our tests is the average annual children's cable subscription rate when the cohort was under three because, as discussed 
earlier, much of the medical literature on the subject argues that early childhood television watching is particularly detrimental. Also, since autism is thought to develop by age three, any trigger for autism would have to be such that exposure occurs prior to age three. We adjust the standard errors to allow error terms to be correlated between birth cohorts within a county or IU. ${ }^{14}$

One empirical challenge is that families predisposed to having children with mental retardation or families predisposed to having children with autism may, for one reason or another, locate disproportionately in counties/IUs that experienced rapid growth of children's cable subscription rates. We address this concern by estimating fixed effects regressions that control for time-invariant county/IU variables (both measured and unmeasured) that may affect mental retardation rates and/or autism rates, such as clinical criteria used by local clinicians.

Including fixed effects may not fully control for the effect of county/IU variables on health outcomes if the introduction and growth of children's cable is correlated with time-varying county/IU variables. Table 2 presents the results of a a regression where each county's or IU's children's cable subscription rate in 1992 is the dependent variable and the independent variables are changes in county/IU demographic variables between 1972 and 1992, including per capita income, population, and proportions of various racial/ethnic groups. ${ }^{15}$ We find that children's cable grew relatively rapidly in counties that experienced relatively rapid growth in the proportion of the population that is black. This suggests that changes in county/IU-level variables over our 20-year period had some effect on children's cable growth, so in some of our regressions we also include time-varying county/IU demographic variables. We also report results from regressions that include county-specific time trends rather than time-varying county/IU demographic variables to control for time-varying county/IU variables.

\footnotetext{
${ }^{14}$ An alternative approach would be to focus on the year that children's cable was introduced into the county or IU rather than the children's cable subscription rate when the cohort was below three. However, because there is little variability across counties/IUs in the dates in which children's cable was introduced, this alternative is not a useful approach in this case.

${ }^{15}$ In 1972 the children's cable subscription rate was zero for all counties and IUs, so the children's cable subscription rate in 1992 always equals the growth in the children's cable subscription rate between 1972 and 1992.
} 
A second concern is that some California counties did not have a regional developmental services center during our sample period, which likely means a smaller proportion of children diagnosed with mental retardation or autism who were originally born in those counties were recorded in our data set as eventually residing in those counties. This could arise both because some families with mentally retarded or autistic children born in counties without a regional center may have moved to a county with a regional center (because regional centers provide services) and because some families who did not move may never have registered at a regional center because of the distance to the nearest center.

In our regressions we consider the correlation at the county/IU cohort level between children's cable subscription rates and mental retardation rates or autism prevalence rates. Because, as just discussed, an unknown and likely varying number of each cohort's mentally retarded or autistic children born in California counties without a regional center were not included in our data as residing in that county, any measured correlation between children's cable and mental retardation or autism in those counties is likely to be substantially smaller. To address this, we allow children's cable to have a separate effect in California counties without a regional center and focus on the children's cable coefficient for the Pennsylvania IUs and the California counties with a regional center where, if children's cable is correlated with mental retardation or autism, the correlations should be stronger.

Another concern is that mental retardation rates or autism diagnosis rates could change over time because, for example, of changes in diagnostic criteria. To address this concern we include a full set of birth-year indicator variables, which allows for a non-linear change in mental retardation rates and autism diagnosis rates over time. Including birth-year indicator variables is especially important in the autism regressions given the substantial growth in the autism diagnosis rate over time in all states. 16,17

\footnotetext{
16 We include birth-year indicator variables rather than state-specific birth-year indicator variables. We do this because cable subscription rates grew in a similar manner between counties/IUs within each state. When we regress children's cable on birth-cohort indicator variables for Pennsylvania IUs the R-squared is 0.72, while a similar regression for California counties yields 0.43 (for California counties with a regional center the value is 0.72 ). Given these high R-squared values, including state-specific birth-year indicator variables in our regressions would absorb much of the variation we rely on to identify the correlation between children's cable and mental retardation and children's cable and autism. See footnote 24 for further discussion.
} 
Finally, because the mental retardation and autism rates were low in most counties, especially for autism in the 1970s, a small absolute change in the rate often represents a large percentage change. We therefore report results both when the dependent variable is measured as a prevalence per 100 population and when it is measured as the natural log of the prevalence rate per 100 population. ${ }^{18}$

C) $\underline{\text { Results }}$

Table 3 reports sample statistics by birth cohort for mental retardation rates, autism diagnosis rates, general cable subscription rates, and children's cable subscription rates; Figures 1 and 2 depict mental retardation rates and autism diagnosis rates by birth cohort; and Figure 3 shows how different percentiles of the children's cable subscription rate by county/IU vary over our sample period. A few aspects of the data are worth highlighting. First, the autism diagnosis rate grew substantially during our sample period (and continued to grow substantially afterward). Second, early in the sample period there was growth in the mental retardation rate while late in the period it fell and ended close to the initial value. Third, both general cable and children's cable subscription rates grew substantially during the sample period. Fourth, children's cable rates were zero early in our sample. Fifth, the children's cable subscription rate varies substantially across counties/IUs late in the sample period after children's cable is introduced in the late 1970s/early 1980s. ${ }^{19}$

We begin our empirical analysis with the basic specifications described in equation (2) above. The first two columns of Table 4 report results of county/IU fixed effects regressions for mental retardation with a full set of birth-year indicator variables included but without time-varying county/IU

${ }^{17}$ If autism diagnostic criteria have expanded over time, some children who may have previously been diagnosed with mental retardation might be diagnosed with autism. At a county level, this might result in a clinical substitution of autism cases for mental retardation cases. This phenomenon should not affect our results unless the diagnostic substitution is correlated with the growth of children's cable, which seems unlikely.

${ }^{18}$ For autism there are some observations for which the prevalence rate equals zero. In the autism regressions where the dependent variable is measured as the natural log of the prevalence rate, we record the prevalence rate as 0.01 so that the natural $\log$ of the prevalence rate is defined for these observations.

${ }^{19} \mathrm{We}$ do not report descriptive data by state. Looking at the descriptive data broken down by state the only important differences are that mental retardation rates are higher in Pennsylvania than in California, the autism diagnosis growth rate was higher in Pennsylvania than in California, and children's cable rates were higher in Pennsylvania than in California. 
demographic variables or county/IU specific time trends. In column 1 the dependent variable is the mental retardation rate (multiplied by 100) by birth cohort and county/IU while in column 2 the dependent variable is the natural log of the mental retardation rate (multiplied by 100) by birth cohort and county/IU, where in each regression the explanatory variable of interest is the average annual county/IU children's cable subscription rate in Pennsylvania IUs and California counties with a regional center when the birth cohort was below three. In both columns the coefficient on this main cable variable is negative and statistically significant at the one-percent level. In both columns we also find a positive coefficient on the children's cable subscription rate for California counties without a regional center, where the column 1 coefficient is statistically significant at the five-percent level.

In columns 3 and 4 of Table 4 we include time-varying county/IU demographic variables (per capita income, population, and proportions of various racial/ethnic groups), while in columns 5 and 6 we include county/IU specific time trends rather than time-varying county/IU demographic variables. With time-varying county/IU demographic variables the coefficients on the main cable variable continue to be negative, where they are now statistically significant at the five-percent level. Also, we continue to find positive coefficients on the children's cable subscription rate for California counties without a regional center, where the column 3 coefficient is statistically significant at the 10-percent level. When we include county/IU specific time trends the coefficients on the main cable variables continue to be negative, but they are no longer statistically significant at standard confidence levels. Also, the coefficient on the children's cable subscription rate for California counties without a regional center is now not statistically significant in both regressions.

Table 5 reports the results of a similar set of regressions using data on autism rather than mental retardation diagnoses. We begin by describing the regression results in columns 1 and 2 that do not include time-varying county/IU demographic variables or county/IU specific time trends. In both regressions the main cable coefficient is positive, where it is statistically significant at the 10 percent level in column 1 and at the one percent level in column 2. That is, increases in children's cable subscription rates in Pennsylvania IUs and California counties with a regional center were associated with increases in 
subsequent autism diagnosis rates. Also, for the cable variable for California counties without a regional center, the coefficient is negative in both regressions and statistically significant at the five-percent level in column 2.

In columns 3 and 4 of Table 5 we add time-varying county/IU demographic variables, while in columns 5 and 6 we add county/IU specific time trends. With time-varying county/IU demographic variables the coefficients on the main cable variable continue to be positive, where the coefficient is statistically significant at the five-percent level in column 3 and the one-percent level in column 4. Also, the coefficients on the children's cable variable for California counties without a regional center are both still negative but now neither is statistically significant at standard confidence levels. With county/IU specific time trends the coefficients on the main cable variable are both positive and statistically significant at the one-percent level, while the coefficients on the children's cable variable for California counties without a regional center are now both positive but not statistically significant at standard confidence levels.

We next examine the role of precipitation on autism diagnoses. One possibility concerning the autism results in Table 5 is that the positive coefficients on the main cable variable may not be due to early childhood television watching being a trigger for autism but rather to some other factor positively associated with precipitation being a trigger. That is, Waldman et al. (2008) find a positive correlation between the precipitation a cohort experiences prior to age three and the cohort's subsequent autism diagnosis rate, where the interpretation put forth in that paper is that there is an environmental trigger for autism positively correlated with precipitation that drives up the autism diagnosis rate when precipitation prior to age three is high. Possibilities include any potential trigger positively associated with indoor activity such as early childhood television watching, which is the focus here, vitamin D deficiency which could be more common when children are indoors more and not exposed to the sun, and any indoor chemical where exposure will be higher when the child spends more time indoors.

So one possibility concerning the results in Table 5 is that cable and precipitation are positively correlated and early childhood television watching is not a trigger for autism. In this scenario the positive 
and statistically significant cable coefficients found in the table would not be due to the positive correlation between cable and early childhood television watching, but rather to one of these other factors being the trigger and the positive coefficients arise because cable, through a correlation with precipitation, is also correlated with this unknown "other" trigger.

To address this concern, in Table 6 we rerun the autism regressions of Table 5 but include as additional explanatory variables the average annual precipitation a county/IU cohort experiences prior to age three for Pennsylvania IUs and California counties with a regional center, and a similar variable for California counties without a regional center. As is clearly seen, introducing these precipitation variables has little effect on the magnitudes of the main cable coefficients or their statistical significance. Also, the signs of the coefficients on the children's cable variable for California counties without a regional center are unchanged, although in the column 6 regression with county/IU specific time trends where the dependent variable is the natural log of the autism prevalence rate this coefficient is now positive and statistically significant at the five-percent level. 20

The other finding of interest in Table 6 is that the coefficient on the main precipitation variable is positive in all six regressions which is consistentwith the results in Waldman et al. (2008), where these coefficients are not statistically significant in columns 1 through 4 but statistically significant at the onepercent level in columns 5 and 6 . In other words, the results in columns 5 and 6 are consistent with the conclusion in Waldman et al. (2008) that there is an environmental trigger for autism positively correlated with precipitation. 21

Our last set of regressions involve investigating age-specific correlations between children's cable and our two health outcomes. Earlier results show evidence of a negative correlation between cable subscription rates before a cohort is age three and subsequent mental retardation rates. What we want to investigate now is the correlation between mental retardation rates and separately children's cable

\footnotetext{
${ }^{20} \mathrm{We}$ have also rerun the regressions in Table 4 introducing precipitation variables and there was no change in the qualitative nature of the coefficients on the main cable variables.

${ }^{21}$ Waldman et al. (2008) examined children in California, Oregon, and Washington counties born between 1987 and 2005. Thus, there is some but limited overlap concerning the data studied here and the data considered in that earlier study.
} 
subscription rates for a birth cohort at each of ages zero, one, and two. The correlation could differ by age for a number of reasons including that television watching increases with age over the three-year interval. We also want to investigate the analogous issue concerning children's cable subscription rates and autism diagnosis rates.

As seen in Table 7, children's cable subscription rates are highly correlated between these three ages and with the average children's cable subscription rate for a birth cohort's first three years. ${ }^{22}$ Not surprisingly given these correlations, regressions like those in Tables 4 and 5 but with a single agespecific children's cable rate substituted for each average children's cable rate yields strong negative correlations between cable and mental retardation and strong positive correlations between cable and autism. But such tests tell us little concerning which age-specific children's cable rates are most important.

Our empirical approach is thus to include all three age-specific children's cable subscription rates in the regression analysis. In Table 8 we rerun the regressions in Table 4 but for each original children's cable variable there are now three variables - a children's cable subscription rate when the cohort was age zero, a children's cable subscription rate when the cohort was age one, and a children's cable subscription rate when the cohort was age two.

Without time-varying demographic variables or county-specific time trends in columns 1 and 2, the main age-two children's cable coefficient is negative and statistically significant at the five-percent level in both regressions, while the only other statistically significant coefficient is the main age-zero children's cable coefficient in column 2 which is also negative and statistically significant at the fivepercent level. With time-varying demographic variables in columns 3 and 4 we see a similar pattern. That is, the coefficients on the main age-two children's cable subscription variables are both negative and statistically significant at the five-percent level, while the coefficient on the main age-zero children's cable variable is negative and statistically significant at the five-percent level in column 4 . With

\footnotetext{
22 For the correlations in Table 7, the variables are first expressed as deviations from the county mean in order to focus on the correlations within rather than between counties.
} 
county/IU specific time trends the main age-two children's cable coefficient is negative and statistically significant at the five-percent level in column 5 and negative but not statistically significant in column 6 . That is, five of the six coefficients on the main age-two children's cable variable are negative and statistically significant at the five-percent level, while there is limited evidence of a negative correlation between mental retardation rates and the main age-zero children's cable variable and basically no evidence of a negative correlation for the main age-one children's cable variable. So it seems that the negative coefficients on the main children's cable variable in columns 1 through 4 of Table 4 are being driven primarily by a negative correlation between mental retardation rates and children's cable subscription rates when cohorts are age two.

In Table 9 we rerun the regressions of Table 5 but for each original children's cable variable we again substitute the three corresponding age-specific children's cable variables. Without time-varying demographic variables or county-specific time trends the main age-one cable coefficient is positive, where it is statistically significant at the one-percent level in column 1 and at the five-percent level in column 2 . The only other statistically significant main cable coefficient is the age-two coefficient in column 2, which is positive and statistically significant at the 10 -percent level. With time-varying demographic variables we see the same pattern. The main age-one cable coefficients are both positive and statistically significant at the one- or five-percent levels, while the main age-two cable coefficient in column 4 is positive and statistically significant at the 10-percent level. With county-specific time trends in columns 5 and 6 the results have a different pattern. The main age-one coefficients are again positive and statistically significant, where both coefficients are now statistically significant at the one-percent level. But now the main age-zero cable coefficients are also both positive and statistically significant, where the column 5 coefficient is significant at the one-percent level and the column 6 coefficient is significant at the 10-percent level. Finally the main age-two coefficient in column 5 is negative and statistically significant at the one-percent level. 23 So it seems that the positive coefficients on the main

\footnotetext{
${ }^{23}$ We also find that the coefficient on the age-zero children's cable variable for California counties without a regional center is negative and statistically significant at the 10-percent level in columns 1 and 3.
} 
children's cable variable in Table 5 are driven to a large extent by a positive correlation between autism rates and age-one children's cable rates and to a lesser extent by a positive correlation between autism rates and age-zero children's cable rates. ${ }^{24}$

\section{Discussion}

This study uses a natural experiment to investigate empirically the health consequences of early childhood television watching. In Section III we provided evidence that television watching when children are under three increases with the probability that a household subscribes to children's cable. So if early childhood television watching affects health outcomes, then the frequency of these health outcomes for a county/IU birth cohort should be correlated with the average children's cable subscription rate in the county when the cohort was below three. We investigated this prediction for both mental retardation and autism.

We found that in Pennsylvania IUs and California counties with a regional developmental services center, the mental retardation rate is lower for birth cohorts where a relatively large percentage of households subscribed to children's cable when the cohort was under three, even after including county/IU fixed effects, time-varying county/IU demographic variables, and birth-year indicator variables. However, the result is not robust to the introduction of county/IU specific time trends. In contrast, the same statistical approach yields that in Pennsylvania IUs and California counties with a regional developmental center the autism diagnosis rate is higher for birth cohorts in which a relatively large percentage of households subscribed to children's cable when the cohort was under three, where this result is robust to the introduction of county/IU specific time trends.

24 Including precipitation variables in the Table 9 regressions does not change the finding that the main age-one children's cable coefficient is consistently positive and statistically significant at either the one or five percent levels. Also, as indicated in footnote 16, in most of our tests when we include state-specific birth-year indicator variables the results are insignificant. However, when we include state-specific birth-year indicator variables in the regressions of columns 1 through 4 of Table 9 the main age-one children's cable coefficient remains positive and statistically significant at the five-percent level in each regression (including state-specific birth-year indicator variables in the column 5 and 6 tests would over control for time and create colinearity between the state-specific indicator variables and the county-specific time trends). 
We also extend this analysis in two ways. First, we find that our results concerning autism and children's cable are unchanged when a county/IU precipitation variable is included in the regression analysis, so these results are not due to a correlation between county/IU cable subscription rates and county/IU precipitation. Interestingly, in this set of tests we also find some evidence that autism and precipitation are positively correlated even when controlling for access to cable, consistent with results found in Waldman et al. (2008). Second, we investigate age-specific correlations between cable and our two health outcomes. Our analysis suggests that the negative correlation between mental retardation and children's cable is mostly driven by a negative correlation between mental retardation and the age-two children's cable subscription rates, while the positive correlation between autism and children's cable is mostly driven by a positive correlation between autism and the age-one and to some extent age-zero children's cable-subscription rates. Also, in this set of tests we even find evidence for a negative correlation between mental retardation and age-two children's cable subscription rates when we include county/IU specific time trends.

The magnitudes of the measured relationships are substantial. Consider first children's cable and mental retardation. The average value for the children's cable subscription rate in Pennsylvania IUs and California counties with a regional center in 1992 (and thus the average growth between 1972 and 1992) was 51.7 percentage points. Multiplying this figure by the coefficient on the children's cable variable for Pennsylvania IUs and California counties with a regional center in column 1 of Table 4, -0.00423, yields 0.219 , or 20.6 percent of the mean mental retardation rate in these counties for the 1992 birth cohort (1.06 per 100 children). That is, if the mental retardation results are indeed due to growth in children's cable reducing mental retardation, then the column 1 regression of Table 4 indicates that the mental retardation rate for the 1992 birth cohort in Pennsylvania IUs and California counties with a regional center would have been 20.6 percent higher absent the growth in cable. ${ }^{25}$

\footnotetext{
25 Some of our other mental retardation results suggest smaller effects. For example, doing a similar calculation employing the coefficients from column 3 of Table 4 indicates that the mental retardation rate for the 1992 birth cohort in Pennsylvania IUs and California counties with a regional center would have been 15.3 percent higher absent the growth in children's cable.
} 
Now consider children's cable and autism. Multiplying the 51.7 percentage point increase in children's cable subscriptions by the coefficient on the children's cable variable for Pennsylvania IUs and California counties with a regional center in column 1 of Table $5,0.00074$, yields 0.038 , or 17.1 percent of the mean autism rate in those counties for the 1992 birth cohort ( 0.224 per 100 children). That is, if our autism results are indeed due to growth in children's cable increasing autism, then the column 1 regression of Table 5 indicates that the autism diagnosis rate for the 1992 birth cohort in Pennsylvania IUs and California counties with a regional center would have been 17.1 percent lower absent the growth in children's cable. 26

We can also use this figure to estimate how much of the growth in the autism diagnosis rate between the 1972 and 1992 birth cohorts in Pennsylvania IUs and California counties with a regional center is due to growth in children's cable. In our sample the autism diagnosis rate for the 1972 birth cohort in Pennsylvania IUs and California counties with a regional center is 0.011 percent and for the 1992 birth cohort is 0.224 percent. Simple calculation, i.e., $[0.038 /(0.224-0.011)]^{*} 100$, yields 18.0 percent as the estimate of the proportion of the growth in the autism diagnosis rate between the 1972 and 1992 birth cohorts in Pennsylvania IUs and California counties with a regional center due to growth in children's cable.

There are several potential issues concerning our empirical approach and findings. One is that families more prone to having mentally retarded children may locate in areas with low children's cable subscription rates, or such areas might use narrow diagnostic criteria for diagnosing mental retardation. And similarly, families more prone to having autistic children may locate in areas with high children's cable subscription rates, or such areas might use broad diagnostic criteria for diagnosing autism.

However, this is unlikely to explain our autism results because in our regression analysis we employ county/IU fixed effects, which control for unmeasured time-invariant variables between counties/IUs and

\footnotetext{
${ }^{26}$ Some of our other autism results suggest larger effects. For example, doing a similar calculation employing the coefficient from the logarithmic specification in column 2 of Table 5 indicates that the autism diagnosis rate for the 1992 birth cohort in Pennsylvania IUs and California counties with a regional center would have been 56.0 percent lower absent the growth in children's cable.
} 
our autism results are robust to including either time-varying county/IU demographic variables or county/IU specific time trends. On the other hand, this issue is more of a concern for our mental retardation findings since in Table 4 those results are not robust to including county/IU specific time trends, but interestingly we do find a significant negative coefficient on the main age-two children's cable variable in column 5 of Table 8 , which includes county/IU specific time trends.

A second potential concern is reverse causality, i.e., children prone to developing mental retardation may watch less television, on average, while children prone to developing autism may watch more television, on average. However, our natural experiment methodology eliminates this as a concern. For example, although it is possible that families with an above average probability of having a child with mental retardation may be less likely to subscribe to children's cable, the number of such predisposed families is very likely too small to decrease subscription rates meaningfully.

Another concern is that there may be other factors correlated with children's cable subscription rates driving the results. We think this is unlikely for our results concerning children's cable and mental retardation. Table 8 strongly suggests that our finding of a negative correlation between children's cable and mental retardation rates is due primarily to a negative correlation between age-two children's cable subscription rates and subsequent mental retardation rates. This is easy to explain if the reason for the negative correlation is that higher children's cable subscription rates mean higher early childhood television watching. That is, as discussed in Section II, there are results in the medical literature as well as results in Gentzkow and Shapiro (2008) consistent with preschool television watching having positive effects on cognitive abilities. So one explanation for our mental retardation findings is that there are positive effects on cognitive abilities of childhood television watching as found earlier and it is simply that these positive effects start at an earlier age than a reading of the medical literature might suggest. If, on the other hand, there is some other factor driving the negative correlation, it would need to be more highly correlated with age-two children's cable subscription rates than with age-zero or age-one children's cable subscription rates which seems to us possible but unlikely. 
One alternative explanation for our autism findings is that young children in families with a children's cable subscription spend more time indoors and there is an environmental trigger for autism, other than early childhood television watching, associated more with indoor than outdoor activities. In Table 6 we find some evidence consistent with this possibility. If exposure to the environmental trigger goes up generally with indoor activity, then precipitation - since it causes children to spend more time indoors - should be positively correlated with autism even after controlling for the children's cable subscription rate. Since in two of the six regressions in Table 6 the main precipitation coefficient is positive and statistically significant at either the one- or five-percent level, the Table 6 results are to an extent consistent with this alternative explanation. But note that another explanation for the positive and significant precipitation coefficients in Table 6 is that precipitation results in young children spending more time indoors and as a result watch more television and early childhood television watching is a trigger for autism.

A final concern is that some children move across counties between the date of their birth and when they are recorded in our data. But such measurement error would bias the cable coefficients towards zero, and therefore would work against finding statistically significant results.

One possible criticism of our findings concerning autism is that we do not provide a mechanism through which early childhood television watching could serve as a trigger for autism. But we believe such a criticism would be misplaced. First, sufficiently little is known about how autism operates that most other studies focused on identifying triggers for autism similarly do not provide detailed mechanisms for how the potential trigger investigated could serve as a trigger. This includes the air pollution study in Windham et al. (2006), the study of agricultural pesticides in Roberts et al. (2007), and Larsson et al. (2009) which finds evidence that exposure to phthalates serves as a trigger.

Second, mechanisms have been suggested for how early childhood television watching could lead to attention problems in the general population such as the use of rapidly changing images in many childrens' shows leading to attention problems when the television is off and real life moves more slowly (Sigman, 2007). So one possibility is that early childhood television watching causes attention problems 
in the general population as found in a number of studies including Christakis et al. (2004) and Landhuis et al. (2007), while for a genetically vulnerable population this same mechanism results in early childhood television watching serving as a trigger for autism. Also, McDowell $(2004,2011)$ provides a mechanism specifically focused on how early childhood television watching could serve as a trigger for autism. In his argument the television watching contributes to a "failure of infant-mother eye-contact" and this, in turn, results in autism.

\section{Conclusion}

In this paper we provide evidence that mental retardation rates are negatively correlated and autism rates positively correlated with the average county/IU children's cable subscription rate when a cohort is between zero and two. We also consider age-specific children's cable subscription rates and find that the negative correlation between children's cable and mental retardation is primarily due to the age-two children's cable subscription rate, while the positive correlation between children's cable and autism seems mostly due to the age-one and to some extent age-zero children's cable subscription rates.

We believe the most likely explanation for our mental retardation findings is that for the typical child television watching at age two improves cognitive development and decreases diagnoses of mental retardation, which is typically defined as an IQ below 70 or 75 . This explanation for our mental retardation findings is consistent with Gentzkow and Shapiro (2008), who use a similar natural experiment methodology and find results consistent with increased exposure to preschool television raising standardized test scores during adolescence, although Gentzkow and Shapiro's focus is mostly on children older than two. It is also interesting to note that Gentzkow and Shapiro's findings are consistent with disadvantaged children having the largest positive effect from increased television exposure. This is also consistent with our findings in the sense that it is the disadvantaged who are likely the group whose children are most likely to receive a diagnosis of mental retardation. 27

\footnotetext{
27 This argument is related to the finding in the childhood development literature that early childhood interventions are frequently most effective for children who are relatively disadvantaged. See Currie (2001) for a discussion.
} 
In terms of our autism findings, we believe the most likely explanation is that there is a genetically vulnerable group for which early childhood television watching serves as a trigger for autism. It has long been known that autism has a strong genetic component (see e.g., Rimland (1964) and Folstein and Rutter (1977)). So one explanation for our autism results is that at least for some children diagnosed with autism it is not the genetics alone which triggers the condition, but rather the genes create a vulnerability to autism that is sometimes triggered by early childhood television watching.

There is, however, another possible explanation for our findings. It is possible that early childhood television watching does not decrease mental retardation nor increase autism, but some other factor (or factors) correlated with cable subscription rates decreases mental retardation and increases autism. We think this alternative explanation is particularly unlikely for our mental retardation findings because of our finding that the negative correlation between mental retardation and children's cable subscription rates is primarily due to a negative correlation between mental retardation and age-two children's cable subscription rates. This is easily explained if the reason for the negative correlation between mental retardation and children's cable is due to higher children's cable rates resulting in higher childhood television watching since there is already evidence of positive cognitive effects of childhood television watching at slightly older ages. Any alternative factor would need to be more highly correlated with age-two children's cable subscription rates than with age-zero or age-one rates, which is certainly a possibility but we see no likely candidates.

For our autism results we feel it is more plausible that some other factor or factors correlated with children's cable subscription rates is driving the results. In particular, one alternative scenario is that having children's cable in a household causes young children to spend more time indoors and there is a trigger for autism, other than early childhood television watching, associated more with indoor rather than outdoor activities. Our finding of a positive correlation between autism and precipitation found in some of the regressions reported in Table 6 is consistent with this possibility, although these findings can also be explained by early childhood television watching being a trigger for autism. 
We believe our results are sufficiently suggestive of early childhood television watching decreasing mental retardation and increasing autism that clinical studies focused on the health effects of early childhood television watching are warranted. Only a clinical study can show definitively the health effects of early childhood television watching. 


\section{References}

American Academy of Pediatrics Committee on Public Education, "Policy Statement: Children, Adolescents, and Television," Pediatrics, 107, 2001, pp. 423-426.

Anderson, D.R. and T.A. Pempek, "Television and Very Young Children," American Behavioral Scientist, 48, 2005, pp. 505-522.

Bazar, K.A., A.J. Yun, P.Y. Lee, D.M. Stephanie, and J.D. Doux, "Obesity and ADHD may Represent Different Manifestations of a Common Environmental Oversampling Syndrome: A Model for Revealing Mechanistic Overlap Among Cognitive, Metabolic, and Inflammatory Disorders," Medical Hypotheses, 66, 2006, pp. 263-269.

Christakis, D.A., "The Effects of Infant Media Usage: What Do We Know and What Should We Learn," Acta Paediatrica, 98, 2009, pp. 8-16.

Christakis, D.A., F.J. Zimmerman, D.L. DiGiuseppe, and C.A. McCarthy, "Early Television Exposure and Subsequent Attentional Problems in Children," Pediatrics, 113, 2004, pp. 708-713.

Currie, J., "Early Childhood Education Programs," Journal of Economic Perspectives, 15, 2001, pp. 213-238.

Department of Developmental Services, Changes in the Population of Persons with Autism and Pervasive Developmental Disorders in California's Developmental Services System: 1987 through 1998, California Health and Human Services Agency: Sacramento, CA, 1999.

Department of Developmental Services, Autism Spectrum Disorders, Changes in the California Caseload, An Update: 1999 through 2002, California Health and Human Services Agency: Sacramento, CA, 2003.

Easterbrook, G., "In Search of the Cause of Autism: How About Television?," Slate Magazine, September 5, 2006.

Folstein, S. and M. Rutter, "Infantile Autism: A Genetic Study of 21 Twin Pairs," Journal of Child Psychology and Psychiatry, 18, 1977, pp. 297-326.

Friedrich, L.K. and A.H. Stein, "Aggressive and Prosocial Television Programs and the Natural Behavior of Preschool Children," Monographs of the Society for Research in Child Development, 38 (4, Serial No. 151), 1973.

Gentzkow, M. and J.M. Shapiro, "Preschool Television Viewing and Adolescent Test Scores: Historical Evidence from the Coleman Study," Quarterly Journal of Economics, 123, 2008, pp. 279-323.

Kaiser Family Foundation, Zero to Six: Electronic Media in the Lives of Infants, Toddlers, and Preschoolers, Kaiser Family Foundation: Menlo Park, CA, 2003

Kaiser Family Foundation, The Media Family: Electronic Media in the Lives of Infants, Toddlers, Preschoolers, and their Parents, Kaiser Family Foundation: Menlo Park, CA, 2006.

Kirkorian, H.L., E.A. Wartella, and D.R. Anderson, "Media and Young Children's Learning," Future Child, 18, 2008, pp. 39-61. 
Landhuis, C.E., R. Poulton, D. Welch, and R.J. Hancox, "Does Childhood Television Viewing Lead to Attention Problems in Adolescence? Results from a Prospective Longitudinal Study," Pediatrics, 120, 2007, pp. 532-537.

Larsson, M., B. Weiss, S. Janson, J. Sundell, and C.G. Bornehag, "Associations between Indoor Environmental Factors and Parental-Reported Autism Spectrum Disorders in Children 6- 8 Years of Age," Neurotoxicology, 30, 2009, pp. 822-831.

Linebarger, D.L. and D. Walker, "Infants' and Toddlers' Television Viewing and Language Outcomes," American Behavioral Scientist, 48, 2005, pp. 624-645.

McDowell, M., "Autism, Early Narcissistic Injury, and Self Organization: A Role for the Image of the Mother's Eyes?,” Journal of Analytical Psychology, 49, 2004, pp. 495-520.

McDowell, M., “Autism's Direct Cause? Failure of Infant-Mother Eye-Contact in a Complex Adaptive System," Biological Theory, 5, 2010, pp. 344-356.

Mullen, M., The Rise of Cable Programming in the United States, University of Texas Press: Austin, TX, 2003.

Murray, J.P. and A.D. Murray, "Television: Uses and Effects," in Encyclopedia of Infant and Early Childhood Development, eds., M.M. Haith and J.B. Benson, Academic Press: San Diego, CA, 2008.

Nair, M.K.C., "President’s Page: Autism Spectrum Disorders,” Indian Pediatrics, 41, 2004, pp. 541-543.

Rimland, B., Infantile Autism: The Syndrome and its Implications for a Neural Theory of Behavior, Appleton-Century-Crofts: New York, 1964.

Roberts, D.F. and U.G. Foehr, Kids \& Media in America, Cambridge University Press: Cambridge, United Kingdom, 2004.

Roberts, E.M., P.B. English, J.K. Grether, G.C. Windham, L. Somberg, and C. Wolff, "Maternal Residence Near Agricultural Pesticide Applications and Autism Spectrum Disorders among Children in the California Central Valley,” Environmental Health Perspectives, 115, 2007, pp. 1482-1489.

Rosenzweig, M.R. and K.I. Wolpin, "Natural 'Natural Experiments' in Economics," Journal of Economic Literature, 38, 2000, pp.827-874.

Sigman, A., "Visual Voodoo: The Biological Impact of Watching TV," Biologist, 54, 2007, pp. 14-19.

Waldman, M., S. Nicholson, and N. Adilov, “Does Television Cause Autism?,” NBER Working Paper 12632, 2006.

Waldman, M., S. Nicholson, N. Adilov, and J. Williams, "Autism Prevalence and Precipitation Rates in California, Oregon, and Washington Counties," Archives of Pediatrics \& Adolescent Medicine, 162, 2008, pp. 1026-1034.

Windham, G.C., L. Zhang, R. Gunier, L.A. Croen, and J.K. Grether," Environmental Health Perspectives, 114, 2006, pp. 1438-1444. 
Zimmerman, F.J. and D.A. Christakis, “Children's Television Viewing and Cognitive Outcomes: A Longitudinal Analysis of National Data," Archives of Pediatrics \& Adolescent Medicine, 159, 2005, pp. 619-625.

Zimmerman, F.J., D.A. Christakis, and A.N. Meltzoff, “Associations between Media Viewing and Language Development in Children Under Age 2 Years," The Journal of Pediatrics, 151, 2007, pp. 364368. 


\section{Table 1: Determinants of Television Watching by Children Under the Age of Three}

$\underline{\text { Variable }}$

General cable subscription rate in county

Children's cable subscription rate in county

Weekend day

Child's age (0-6 months is omitted):

6 to 12 months

12 to 18 months

18 to 24 months

24 to 30 months

30 to 36 months

Male

Black (white is omitted)

Hispanic

Other race

Single adult household

Parent's education (years)

Annual family income (\$000)

County's per capita income $(\$ 000)$

Mother works

Constant

Observations

R-squared

\author{
$\underline{\text { Column } 1}$
}

$31.64 * *$

(14.28)

0.91

(4.17)

14.08

(9.26)

$41.67 * * *$

(11.27)

$86.28 * * *$

(11.43)

$96.56^{* * *}$

(11.58)

$111.29 * * *$

(11.38)

3.13

(6.32)

$28.05 * * *$

(9.23)

$-32.67 * * *$

(12.34)

$-4.28$

(15.83)

10.47

(10.09)

$-4.93 * * *$

(1.38)

$-0.12$

(0.079)

0.27

(0.64)

$-3.29$

(6.21)

$45.56^{* *}$

(21.90)

1,229

0.25 $\underline{\text { Column } 2}$

$\underline{\text { Column } 3}$

3.34

(31.45)

$35.11 * * * \quad 32.63$

(12.35) (28.01)

0.89

(4.18)

14.14

(9.19)

$41.28 * * *$

(11.19)

$87.34 * * *$

(11.38)

96.60***

(11.52)

$110.56^{* * * *}$

(11.34)

3.09

(6.35)

$24.60 * * *$

(9.16)

$-33.12 * * *$

(12.05)

$-2.51$

(16.51)

11.48

(10.05)

$-5.07 * * *$

(1.38)

$-0.11$

(0.079)

0.22

(0.62)

$-2.69$

(6.30)

49.48**

(21.24)

1,229

0.25
0.89

14.15

(9.20)

$41.36^{* * *}$

(11.28)

$87.28 * * *$

(11.34)

$96.62 * * *$

(11.55)

$110.66^{* * *}$

(11.63)

3.09

(6.34)

$24.64 * * *$

(9.18)

$-33.06 * * *$

(12.08)

$-2.70$

(15.89)

11.37

(10.14)

$-5.07 * * *$

(1.38)

0.12

(0.079)

0.22

(0.62)

$-2.71$

(6.34)

$48.76^{* *}$

(22.45)

1,229

0.25

Notes: The dependent variable is the number of minutes of TV a child watched on the survey day. $* * *=$ significantly different from zero at the one-percent level; ** = significantly different from zero at the 5percent level. If both parents are present in the house, education is the mother's years of education. Standard errors are clustered by respondent. 
Table 2: Coefficient Estimates of Demographic Factors Associated with the Growth of Child Cable Between 1972 and 1992

$\underline{\text { Variable }}$

Change between 1972

and 1992 in:

Proportion black

Proportion asian

Proportion Hispanic

Per capita income $(\$ 000)$

Population (00000)

Constant

Observations

R-squared $\underline{\text { Coefficient }}$

$\underline{\text { Standard Error }}$

$2.920^{*}$

1.742

0.768

0.989

0.758

0.723

1.152

1.231

0.935

0.936

18.68

15.05

Note: the regression also includes an indicator for Pennsylvania independent units (IUs). *** = significantly different from zero at the one-percent level; $* *=$ significantly different from zero at the fivepercent level; * = significantly different from zero at the 10-percent level. 
Table 3: Mental Retardation and Autism Diagnoses Rates and Cable Penetration by Birth Cohort

$\begin{array}{lllcc}\begin{array}{l}\text { Cohort } \\ \text { birth year }\end{array} & \begin{array}{l}\text { Mean mental } \\ \text { retardation } \\ \text { rate per 100 }\end{array} & \begin{array}{l}\text { Mean autism } \\ \text { rate per 100 }\end{array} & \begin{array}{c}\text { Percentage of households subscribing to: } \\ \text { General cable }\end{array} & \begin{array}{c}\text { Children's cable } \\ 1972\end{array} \\ 1973 & 0.777 & 0.009 & 26.4 & 0.0 \\ 1974 & 0.963 & 0.012 & 28.6 & 0.0 \\ 1975 & 1.009 & 0.010 & 30.3 & 0.0 \\ 1976 & 1.017 & 0.014 & 32.0 & 0.0 \\ 1977 & 1.063 & 0.014 & 33.8 & 0.0 \\ 1978 & 1.006 & 0.011 & 35.2 & 0.3 \\ 1979 & 0.951 & 0.019 & 36.9 & 0.7 \\ 1980 & 0.997 & 0.017 & 39.0 & 1.2 \\ 1981 & 0.935 & 0.016 & 41.9 & 2.6 \\ 1982 & 0.856 & 0.018 & 45.9 & 5.5 \\ 1983 & 0.847 & 0.015 & 48.2 & 9.0 \\ 1984 & 0.860 & 0.024 & 49.9 & 13.0 \\ 1985 & 0.838 & 0.024 & 50.9 & 16.5 \\ 1986 & 0.852 & 0.044 & 53.1 & 22.3 \\ 1987 & 0.800 & 0.042 & 55.5 & 37.2 \\ 1988 & 0.765 & 0.044 & 57.9 & 42.2 \\ 1989 & 0.834 & 0.062 & 60.0 & 45.2 \\ 1990 & 0.846 & 0.111 & 61.9 & 47.0 \\ 1991 & 0.853 & 0.096 & 62.8 & 47.3 \\ 1992 & 0.862 & 0.130 & 63.6 & 45.4 \\ & 0.819 & 0.170 & 63.1 & \end{array}$

Notes: cable subscription rates are county-level averages for a birth cohort's first three years (e.g., for the 1972 birth cohort, the percentage of household who subscribed to cable in 1972, 1973, and 1974 
Table 4: Coefficient Estimates for Mental Retardation (MR)

Dependent variable:

Cable subscription rate:

- Pennsylvania IUs and California Counties with a regional center

- California counties without a regional center

County demographics

Proportion black

Proportion asian

Proportion Hispanic

Per capita income $(\$ 000)$

Population (00000)

County-specific time trends

Observations

$\mathrm{R}^{2}$

\begin{tabular}{|c|c|c|c|}
\hline MR Rate & $\underline{\log (\text { MR rate) }}$ & $\underline{\text { MR Rate }}$ & $\underline{\log (\text { MR rate })}$ \\
\hline $\begin{array}{l}-0.00423^{* * *} \\
(0.00148)\end{array}$ & $\begin{array}{l}-0.00576^{* * *} \\
(0.00154)\end{array}$ & $\begin{array}{l}-0.00314 * * \\
(0.00137)\end{array}$ & $\begin{array}{l}-0.00460 * * \\
(0.00135)\end{array}$ \\
\hline $\begin{array}{l}0.00249 * * \\
(0.00106)\end{array}$ & $\begin{array}{c}0.00155 \\
(0.00107)\end{array}$ & $\begin{array}{l}0.00173 * \\
(0.00094)\end{array}$ & $\begin{array}{c}0.00110 \\
(0.00098)\end{array}$ \\
\hline & & $\begin{array}{c}0.00935 \\
(0.02544) \\
0.02986^{* * *} \\
(0.00834) \\
0.03604^{* * *} \\
(0.00937) \\
0.00755 \\
(0.01170) \\
0.00446 \\
(0.01190)\end{array}$ & $\begin{array}{l}-0.03841 \\
(0.02535) \\
0.04483^{* * *} \\
(0.00962) \\
0.02829^{* * *} \\
(0.00871) \\
-0.03800^{* * *} \\
(0.01160) \\
0.01420 \\
(0.01610)\end{array}$ \\
\hline
\end{tabular}

$\begin{array}{cc}\text { NO } & \text { NO } \\ 1,611 & 1,608 \\ 0.14 & 0.08\end{array}$

NO
1,608
0.15

MR Rate

$\underline{\log (\mathrm{MR} \text { rate })}$

$\begin{array}{ll}0.00132 & -0.00039 \\ 0.00128) & (0.00111) \\ 0.00033 & -0.00017 \\ 0.00077) & (0.00089)\end{array}$

Note: a full set of county/IU fixed effects are included in columns 1-6, and a full set of birth cohort fixed effects are included in columns 1-4. Standard errors are clustered at the county/IU level. $* * *=$ significantly different from zero at the one-percent level; $* *=$ significantly different from zero at the five-percent level; * = significantly different from zero at the 10 -percent level. 
Table 5: Coefficient Estimates for Autism Diagnoses

\begin{tabular}{|c|c|c|c|c|c|c|}
\hline Dependent variable: & Autism Rate & $\begin{array}{c}\log \\
\text { (autism rate) }\end{array}$ & Autism Rate & $\begin{array}{c}\text { Log } \\
\text { (autism rate) } \\
\end{array}$ & Autism Rate & $\begin{array}{c}\log \\
\text { (autism rate) } \\
\end{array}$ \\
\hline \multicolumn{7}{|l|}{ Cable subscription rate: } \\
\hline $\begin{array}{l}\text { - Pennsylvania IUs and California } \\
\text { Counties with a regional center } \\
\text { - California counties } \\
\text { without a regional center }\end{array}$ & $\begin{array}{c}0.00074 * \\
(0.00039) \\
-0.00035 \\
(0.00023)\end{array}$ & $\begin{array}{l}0.01330 * * * \\
(0.00304) \\
-0.00249 * * \\
(0.00196)\end{array}$ & $\begin{array}{l}0.00078 * * \\
(0.00032) \\
-0.00036 \\
(0.00027)\end{array}$ & $\begin{array}{l}0.01198 * * * \\
(0.00330) \\
-0.00206 \\
(0.00202)\end{array}$ & $\begin{array}{l}0.00107 * * * \\
(0.00036) \\
0.00021 \\
(0.00019)\end{array}$ & $\begin{array}{l}0.01577 * * * \\
(0.00415) \\
0.00425 \\
(0.00266)\end{array}$ \\
\hline \multicolumn{7}{|l|}{ County demographics } \\
\hline Proportion black & & & $\begin{array}{c}0.00213 \\
(0.00605)\end{array}$ & $\begin{array}{c}0.05693 \\
(0.07464)\end{array}$ & & \\
\hline Proportion asian & & & $\begin{array}{l}-0.00669 * * \\
(0.00325)\end{array}$ & $\begin{array}{l}-0.02962 \\
(0.03119)\end{array}$ & & \\
\hline Proportion Hispanic & & & $\begin{array}{c}0.00136 \\
(0.00434)\end{array}$ & $\begin{array}{l}-0.03215 \\
(0.02283)\end{array}$ & & \\
\hline Per capita income $(\$ 000)$ & & & $\begin{array}{c}0.00423 \\
(0.00391)\end{array}$ & $\begin{array}{c}0.02450 \\
(0.04240)\end{array}$ & & \\
\hline Population (00000) & & & $\begin{array}{l}-0.00151 \\
(0.00545)\end{array}$ & $\begin{array}{l}-0.01740 \\
(0.03190)\end{array}$ & & \\
\hline County-specific time trends & NO & NO & NO & NO & YES & YES \\
\hline Observations & 1,715 & 1,715 & 1,715 & 1,715 & 1,715 & 1,715 \\
\hline $\mathrm{R}^{2}$ & 0.19 & 0.43 & 0.20 & 0.44 & 0.27 & 0.54 \\
\hline
\end{tabular}

Note: a full set of county/IU fixed effects are included in columns 1-6, and a full set of birth cohort fixed effects are included in columns 1-4. Standard errors are clustered at the county/IU level. $* * *=$ significantly different from zero at the one-percent level; $* *=$ significantly different from zero at the five-percent level; * = significantly different from zero at the 10 -percent level. 
Table 6: Coefficient Estimates for Autism Diagnoses With Precipitation Included

\begin{tabular}{|c|c|c|c|c|c|c|}
\hline Dependent variable: & $\underline{\text { Autism Rate }}$ & $\begin{array}{c}\log \\
\text { (autism rate) } \\
\end{array}$ & $\underline{\text { Autism Rate }}$ & $\begin{array}{c}\log \\
\text { (autism rate) } \\
\end{array}$ & $\underline{\text { Autism Rate }}$ & $\begin{array}{c}\log \\
\text { (autism rate) } \\
\end{array}$ \\
\hline $\begin{array}{l}\text { Cable subscription rate: } \\
\text { - } \quad \text { Pennsylvania IUs and California } \\
\text { Counties with a regional center } \\
\text { - } \quad \text { California counties } \\
\quad \text { without a regional center }\end{array}$ & $\begin{array}{l}0.00076^{* *} \\
(0.00038) \\
-0.00036 \\
(0.00023)\end{array}$ & $\begin{array}{l}0.01314 * * * \\
(0.00305) \\
-0.00229 \\
(0.00199)\end{array}$ & $\begin{array}{l}0.00080 * * \\
(0.00032) \\
-0.00037 \\
(0.00028)\end{array}$ & $\begin{array}{l}0.01177 * * * \\
(0.00329) \\
-0.00180 \\
(0.00207)\end{array}$ & $\begin{array}{l}0.00108 * * * \\
(0.00031) \\
0.00024 \\
(0.00018)\end{array}$ & $\begin{array}{l}0.01591 * * * \\
(0.00360) \\
0.00530 * * \\
(0.00258)\end{array}$ \\
\hline $\begin{array}{l}\text { Average annual precipitation for a } \\
\text { birth cohort's first three years } \\
\text { - } \quad \text { PA IUs and CA counties } \\
\text { with a regional center } \\
\text { - CA counties without } \\
\text { a regional center }\end{array}$ & $\begin{array}{l}0.00044 \\
(0.00070) \\
-0.00023 \\
(0.00030)\end{array}$ & $\begin{array}{c}0.00185 \\
(0.00917) \\
0.00535 \\
(0.00396)\end{array}$ & $\begin{array}{l}0.00042 \\
(0.00060) \\
-0.00019 \\
(0.00033)\end{array}$ & $\begin{array}{c}0.00390 \\
(0.00857) \\
0.00689 * \\
(0.00410)\end{array}$ & $\begin{array}{c}0.00267 * * \\
(0.00074) \\
0.00015 \\
(0.00035)\end{array}$ & $\begin{array}{c}0.02624 * * * \\
(0.00863) \\
0.00575 * \\
(0.00347)\end{array}$ \\
\hline County demographics? & NO & NO & YES & YES & NO & NO \\
\hline County-specific time trend? & NO & NO & NO & NO & YES & YES \\
\hline $\begin{array}{l}\text { Observations } \\
\mathrm{R}^{2}\end{array}$ & $\begin{array}{c}1,715 \\
0.19\end{array}$ & $\begin{array}{c}1,715 \\
0.43\end{array}$ & $\begin{array}{c}1,715 \\
0.20\end{array}$ & $\begin{array}{c}1,715 \\
0.44\end{array}$ & $\begin{array}{l}1,715 \\
0.23\end{array}$ & $\begin{array}{c}1,715 \\
0.46\end{array}$ \\
\hline
\end{tabular}

Note: a full set of county/IU fixed effects are included in columns 1-6, and a full set of birth cohort fixed effects are included in columns 1-4. Standard errors are clustered at the county/IU level. $* * *=$ significantly different from zero at the one-percent level; $* *=$ significantly different from zero at the five-percent level; * = significantly different from zero at the 10 -percent level. 


\section{Table 7: Within-County Correlation in Age-Specific Cable Penetration Rates}

\begin{tabular}{|c|c|c|c|c|}
\hline & $\underline{\text { Age zero }}$ & $\underline{\text { Age one }}$ & $\underline{\text { Age two }}$ & $\begin{array}{l}\text { Average annual } \\
\text { for zero to two }\end{array}$ \\
\hline Age zero & 1.00 & & & \\
\hline Age one & 0.89 & 1.00 & & \\
\hline Age two & 0.78 & 0.88 & 1.00 & \\
\hline $\begin{array}{l}\text { Average annual for } \\
\text { ages zero to two }\end{array}$ & 0.93 & 0.97 & 0.93 & 1.00 \\
\hline
\end{tabular}

Notes: for the above correlations, the variables are first expressed as deviations from the county mean in order to focus on correlations within rather than between counties. The cable penetration rate for a birth cohort between ages zero to two is the average of the three age-specific cable penetration rates. 
Table 8: Coefficient Estimates for Mental Retardation (MR) Allowing for Age-Specific Effects

Dependent variable:

$\underline{\text { MR Rate }}$

$\underline{\log (\text { MR rate) }}$

$\underline{\text { MR Rate }} \quad \underline{\log (\text { MR rate })} \quad \underline{\text { MR Rate }}$

$\underline{\log (\mathrm{MR} \text { rate })}$

Cable subscription rate in Pennsylvania IUs and California with a regional center when cohort is:
- Zero
$-0.00158$
- One
0.00039
$-0.00284^{* *}$
$-0.00046$
- Two
$(0.00109)$
$-0.00312 * *$
$(0.00104)$
$-0.00274 * *$
(0.00114)
$(0.00123)$

$-0.00143$

Cable subscription rate in California counties

without a regional center when cohort is:

\begin{tabular}{|c|c|c|}
\hline Zero & $\begin{array}{c}0.00023 \\
(0.00122)\end{array}$ & $\begin{array}{c}0.00024 \\
(0.00270)\end{array}$ \\
\hline One & $\begin{array}{c}0.00080 \\
(0.00102)\end{array}$ & $\begin{array}{c}0.00089 \\
(0.00209)\end{array}$ \\
\hline Two & $\begin{array}{r}0.00139 * \\
(0.00074)\end{array}$ & $\begin{array}{c}0.00013 \\
(0.00099)\end{array}$ \\
\hline
\end{tabular}

County demographics?

$\begin{array}{cc}\text { NO } & \text { NO } \\ \text { NO } & \text { NO } \\ & \\ 1,611 & 1,608 \\ 0.14 & 0.07\end{array}$

0.00064
$(0.00105)$
$-0.00246^{*}$

$(0.00117)$

0.00014

(0.00132)

$-0.00004$

0.00048

$-0.00246^{* *}$

(0.00091

$(0.00097)$

$-0.00230^{* *}$

$-0.00209^{* *}$

(0.00093)

0.00020

(0.00106)

$(0.00083)$

(0.00114)

$-0.00025$

(0.00124)

$-0.00035$

$-0.00038$

(0.00133)

(0.00243)

0.00081

0.00103

(0.00103)

$(0.00213)$

0.00090

0.00105

0.00008

(0.00104)

(0.00066)

(0.00091)

$-0.00049$

$-0.00083$

(0.00089)

County-specific time trend?

$\begin{array}{cc}\text { YES } & \text { YES } \\ \text { NO } & \text { NO } \\ 1,611 & 1,608 \\ 0.21 & 0.15\end{array}$

NO
YES
1,611
0.39

$-0.00035$

$(0.00285)$

0.00109

(0.00211)

$-0.00148^{*}$

$(0.00083)$

Observations

R-squared

$$
0.14
$$

0.07

NO

YES

1,611

0.26

Note: a full set of county/IU fixed effects are included in columns 1-6, and a full set of birth cohort fixed effects are included in columns 1-4. Standard errors are clustered at the county/IU level. $* * *=$ significantly different from zero at the one-percent level; $* *=$ significantly different from zero at the five-percent level; * = significantly different from zero at the 10 -percent level. 
Table 9: Coefficient Estimates for Autism Diagnoses Allowing for Age-Specific Effects

Dependent variable:

\begin{tabular}{|c|c|}
\hline Autism & $\begin{array}{c}\log \\
\text { (autism ra }\end{array}$ \\
\hline \multicolumn{2}{|l|}{$\begin{array}{l}\text { IUs and } \\
\text { cohort is: }\end{array}$} \\
\hline 0.00014 & -0.00045 \\
\hline$(0.00034)$ & $(0.00380)$ \\
\hline $0.00069 * * *$ & $0.00852 * *$ \\
\hline$(0.00025)$ & $(0.00343)$ \\
\hline-0.00012 & $0.00467^{*}$ \\
\hline$(0.00022)$ & $(0.00248)$ \\
\hline
\end{tabular}

Autism Rate

0.00016
$(0.00031)$
$0.00067 * * *$
$(0.00025)$
-0.00072
$(0.00019)$

$\log$

$\log$

Dependent variable:

Cable subscription rate in Pennsylvania IUs and

California with a regional center when cohort is

\begin{tabular}{|c|c|c|}
\hline - Zero & $\begin{array}{c}0.00014 \\
(0.00034)\end{array}$ & $\begin{array}{l}-0.00045 \\
(0.00380)\end{array}$ \\
\hline - One & $\begin{array}{l}0.00069 * * * \\
(0.00025)\end{array}$ & $\begin{array}{l}0.00852 * * \\
(0.00343)\end{array}$ \\
\hline - $\quad$ Two & $\begin{array}{l}-0.00012 \\
(0.00022)\end{array}$ & $\begin{array}{c}0.00467^{*} \\
(0.00248)\end{array}$ \\
\hline
\end{tabular}

Cable subscription rate in California counties without a regional center when cohort is:

\begin{tabular}{|c|c|c|}
\hline Zero & $\begin{array}{c}-0.00043 * \\
(0.00023)\end{array}$ & $\begin{array}{l}-0.00337 \\
(0.00284)\end{array}$ \\
\hline One & $\begin{array}{c}0.00007 \\
(0.00017)\end{array}$ & $\begin{array}{l}-0.00010 \\
(0.00225)\end{array}$ \\
\hline Two & $\begin{array}{l}-0.00003 \\
(0.00017)\end{array}$ & $\begin{array}{c}0.00056 \\
(0.00202)\end{array}$ \\
\hline
\end{tabular}

County demographics?

$\begin{array}{cc}\text { NO } & \text { NO } \\ \text { NO } & \text { NO } \\ 1,715 & 1,715 \\ 0.19 & 0.43\end{array}$

$-0.00040^{*}$
$(0.00023)$
0.00007
$(0.00017)$
-0.00006
$(0.00019)$

$-0.00290$

$(0.00277)$

$-0.00019$

$(0.00222)$

0.00065

$(0.00202)$

YES
NO
1,715
0.44

$0.00108 * * *$
$(0.00032)$
$0.00078 * * *$
$(0.00021)$
$-0.00083 * * *$
$(0.00026)$

$0.00848 *$

$(0.00437)$

$0.01005^{* * *}$

$(0.00355)$

$-0.00304$

(0.00306)

County-specific time trend?

Observations

$\mathrm{R}^{2}$

YES
NO
1,715
0.20

0.00022
$(0.00021)$
0.00003
$(0.00019)$
-0.00002
$(0.00014)$

0.00389

$(0.00302)$

$-0.00040$

$(0.00277)$

0.00095

(0.00196)

Note: a full set of county/IU fixed effects are included in columns 1-6, and a full set of birth cohort fixed effects are included in columns 1-4. Standard errors are clustered at the county/IU level. $* * *=$ significantly different from zero at the one-percent level; $* *=$ significantly different from zero at the five-percent level; * = significantly different from zero at the 10 -percent level. 
Figure 1: Mean Autism Rate by Birth Cohort, 1972-1992

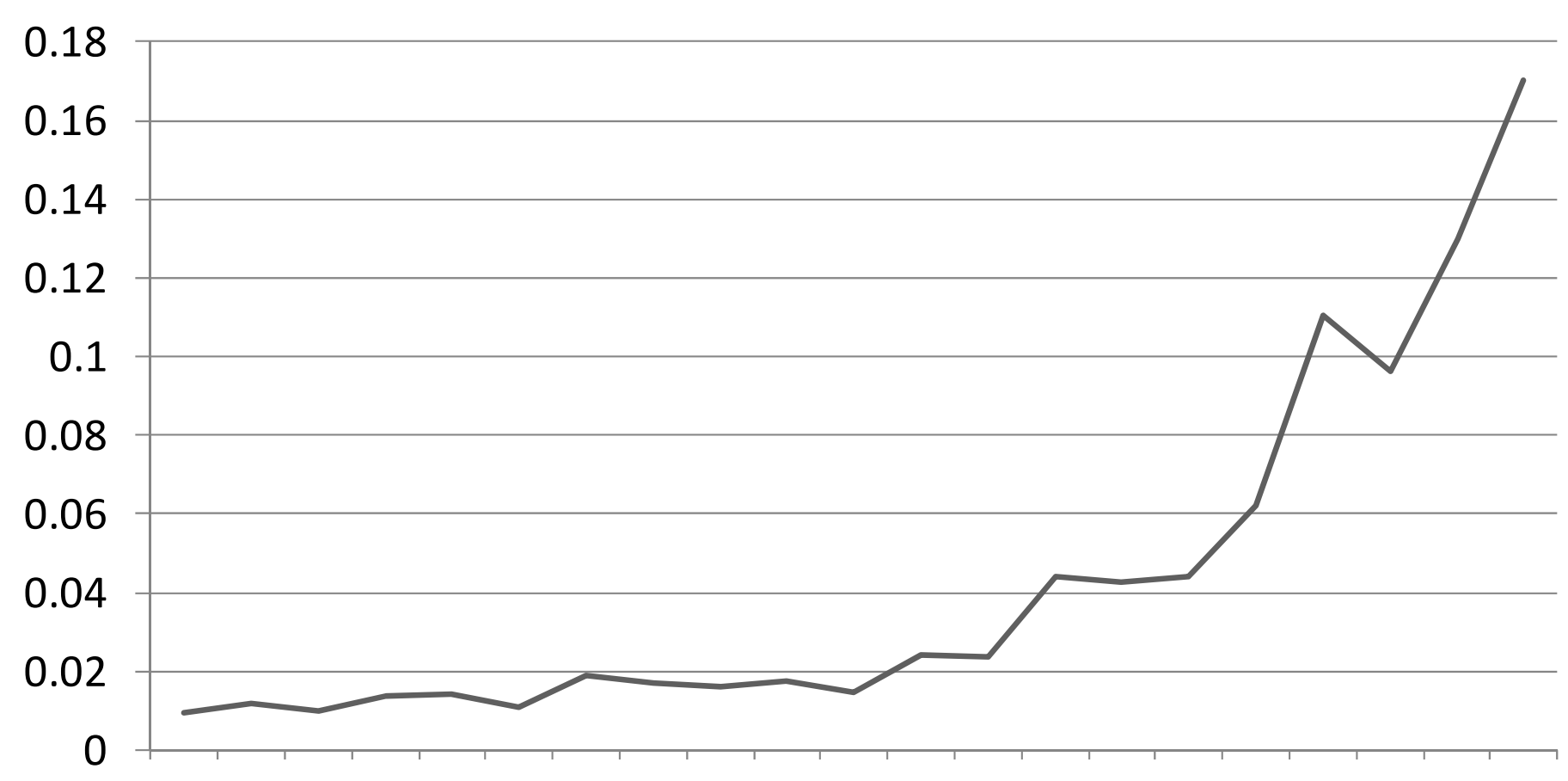

197219731974197519761977197819791980198119821983198419851986198719881989199019911992

Note: autism rate multiplied by 100 for California counties and Pennsylvania intermediate units. 
Figure 2: Mental Retardation Rate by Birth Cohort, 1972-1992

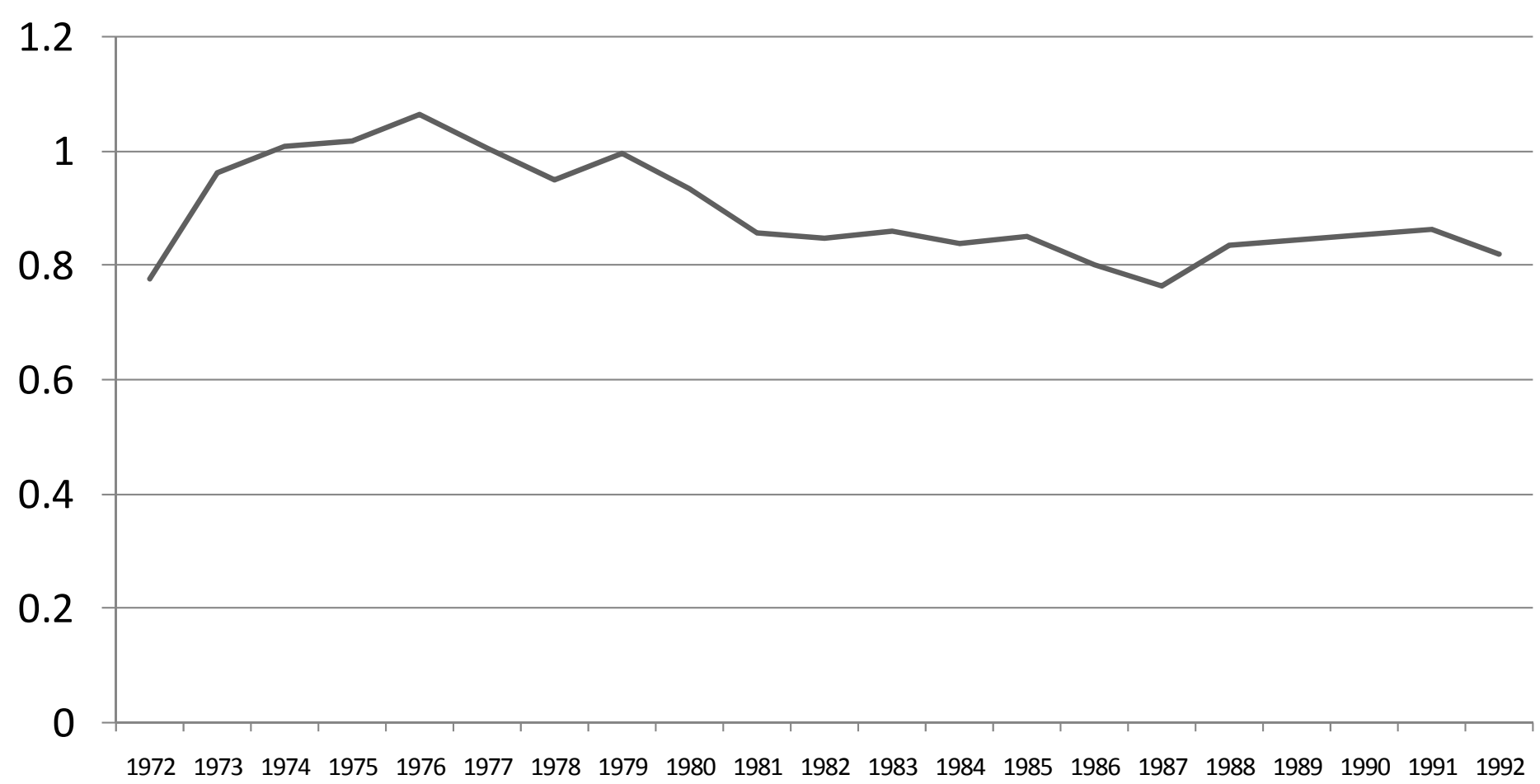

Note: mental retardation rate, multiplied by 100 , for California counties and Pennsylvania intermediate units. 
Figure 3: Child Cable Subscription Rate by Birth Cohort, 1972-1992

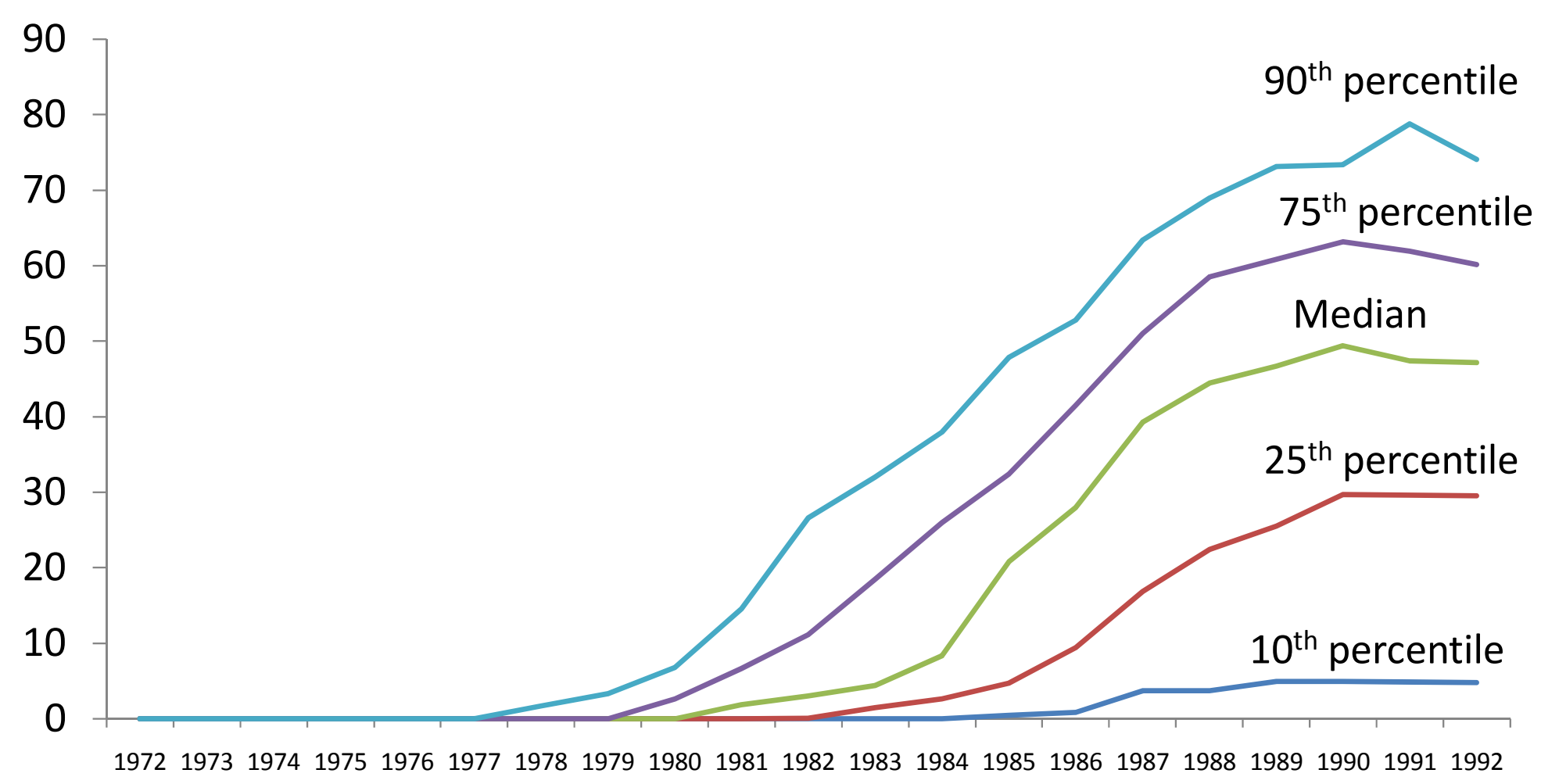

Note: California counties and Pennsylvania intermediate units. Rates are an average of the first three years of a child's life (e.g., 1972, 1973, and 1974 for 1972 birth cohort). 